\title{
The Structure of the Narrative Dialogue in Andalusian Shrines from the Fifth Century AH to the Ninth Century
}

\author{
Zaher Abdul Hussein Jendil \\ Imam Kadhim College of Islamic Sciences, Iraq, Baghdad, Arabic Language Department
}

\begin{abstract}
The research is financed by Imam Al-Kadhum College(IKC) (Sponsoring information)
Abstract

Primary thalamus: Dialogue is an important element of narrative narration, as it is a narrative method used in poetry, story and narrations to depict the characters and push the act forward the techniques of the old text are not hidden, as the features of storytelling appear on the ancient literary text in poetry and prose, as the sender depended on a method Tell or tell, which is called the speech If we go back to the old literary texts, especially the art of standing, and read a new reading, the data of this art are revealed, and we find that it belongs to the storytelling, as we see the clear narrative style, and hardly anyone disagrees that the old texts in general are fertile, seduce critics and attract students as they are full of energies and creativity and the literary aesthetic that nourishes the reader's thought (2). Upon entering the text the Andalusian Maqamah from the fifth century AH to the ninth century AH, we see the impact of the Andalusian civilization clearly on the style of standing in general. Through the mentioned centuries and showing the creativity of Maqamiin the narrative of that era.
\end{abstract}

DOI: $10.7176 /$ JLLL/64-06

Publication date: January $31^{\text {st }} 2020$

Theoretical hypothalamus :

The maqām dialogue represents an art of prose arts and is considered a basic pillar as we mentioned above from the narrative process and storytelling, it is the speech that takes place between two or more people in which communication is carried out with succession of people to send and receive as stated(3)And dialogue, like poetry, is weighed by a balance and cannot be increased(4) Dialogue reveals to us about the characters and time and place Voziv Te intended message performance permission is an interview with a calm generally begins with one of the known application formats Calcaal and order or please under one place, and ends with the launch of the rule of first(5)When we read the shrines from the fifth to the ninth century AH, we stood on dialogue, its patterns, forms, and everything related to it during this period and the change in it, since progress and development at all levels must cast a shadow on the dialogue, especially the great development that affected Andalus. Western literature as a result of its proximity to the Spanish civilization, but rather its saturation and overlap with Spanish literature, as Andalusia opens its doors to all the currents and arts it finds in Arab literature in the Levant and has received a passion, especially what Hamdani and Al-Hariri meant, as the latter specialized in widespread and widespread circulation among the writers and scholars in Andalusia, so I accept Alk Seen from scientists to emulate and Tkulaidaha and given her explanations .

In summary, this research is der a $\mathrm{Q}$ of an important means of narrative structure in the Andalusian shrines since the fifth century to the ninth century, as we examine the parties to dialogue, types and contents, language and the most important functions that ensure achieving Starting from a certain period of time that can contribute and give results on the stages that the dialogue went through in Andalusian Arab literature during this period, the dialogue in the maqam is a clear model for one of the most important means of narration, which is with the event, time, place and plot with an integrated narrative structure that has evolved and has become one of the most important means of storytelling In the following ages .

-The first topic

Types of maqam dialogue

Can evaluate the dialogue, according to the studies that preceded this research into many divisions, including what follows the outer shape of the dialogue and the length of which follows the function, including what followed the methods of mace I e and issuance and centrality, but in fact remains the structure of the title combines all the divisions of the dialog so you choose Almqama dialogue structure to include all divisions The aforementioned and can be divided according to its content :

1- Critical or literary dialogue :

And the critical dialogue begins between two people characterized by presenting the critical opinions of the owner of the maqam, trying the maqam of the maqam to prove his critical opinions through the question and answer of "dialogue" and here they make impressionistic monetary judgments on the poets, their criticism does not come out of the first fruits of the old criticism, and all of this takes place according to a dialogue scene drawn by the writer through his maqam text and we see The method that the Maqamis invented is to place critical opinions on the invalid Sunnis to prove their prestige and preference without showing their true personalities, for they are victorious to themselves and their hair indirectly, including from that of Abd al-Rahman bin Fattuh " 
T 542".(6) He said how did he remind you of the men of your Egypt and your stand on the poets of your time? And the best male said, and he said :

Who punished them, and weighted them by weight? I told the slave, a footnote to the elegant envelope, the preamble of kindness, Abu Hafs bin Bard : He said, "Who among the strongest metaphors?" The most valid similarities? I said Agag sea and OS fiery , ....) ( 7), And such dialogues are found in the shrine of Omar bin Shahid, " the fifth century AH "( 8 ) It could classify the dialogue in which dialogue literary critical and clear cut as we find a saying dialogue was produced by one party, a narrator Vtm send the text to the recipient to only is silence (9) and can Alastelal of the text on the presence of the recipient by saying : - ( I say ... and sang ... then He rose from his place (10) ... Including his saying : - (He said in the chest that the writing industry is a trial of adversity and a profession of professions and a happy one in the service of the country Iqbalah and the wretch of who was his capital and the sane if he brought it out of his flaws who did not enter it in his titles especially that may It addressed in the hands of many of the mob and sold them between the creation Vmoha crown of splendor ....) and Mqamta Alsergsti Alnkaditan " T 538" ( 11 )We find critical dialogue in them clear in the position of " poetry and poets " and the establishment of " systems and prose ", including his saying : -

( I said : What do you think of the misleading king .... Zul-Taj and al-Ikleel said (1 2) ...) It means the person of Al-Qais, so we find the critical denominational dialogue, one of the longest dialogues in Andalusian maqams, expanding to more than one poet of all ages, displaying his critical views in a way that is not Directly via narrative dialogue .

2- Political dialogue :

And we mean that the dialogue that specializes Bomo t policy, governance and criticism of the situation in the country or move towards criticism of the ruling or the judge SPA Tkhaddmt held to be the mediation of this criticism and in a dialogue to enable the writer to express his annoyance and to go into politics without damage and we find it with the shrines of Ibn al-Khatib( 13 ) The political dialogue starts from the title to call it "the status of politics " so that the dialogue in it is clear and pure to go into the context of politics by saying : -

.... He said : Wisdom is my art, which made him an antique, and I lay down a mattress and an ox in it ...

He said : So the goodness of solidarity and solidarity and availability became available, as if his face was covered with a piece of morning if it resulted ... Then he said : And the righteous minister is the best number for you, and deliver your support, for he is the one who protects you from vulgarity and the directing of bastards, and proves the opportunity for you, and alternates in greed and clarification. "

" He said : If the King mangle and reconciliation minister, perhaps benefited politics, unbend measure, and location of the site King hands of Table Q d ..."

We also find political dialogue in "the shrines of Zaragoza "(1 4 ) In " XIII established " also and " established the thirty - sixth and twenty - seventh " is a long dialogue Alsergsti face criticism of his judges Lech Od in politics mediated by his hero and disappears behind the dialogue to be more secure than the tyranny of power .

In it he produces a verbal message " dialogue " sent, giving events a realistic feature . 3- Social dialogue :

The main function of the dialogue is to construct the literary text, as dialogue in the narrative process is the communicative function as well, one of its functions is to build the event, the dialogue is the voice of the event in which the characters express their components and their attributes, and the narrator describes what he is unable to express directly, so we find most of the maqam are social that pronounces a social environmental dialogue descriptive, expressing that era with all its deterioration $t$ values and inconsistencies in behavior and only $\mathrm{x}$ fitting for, and from the words of Ibn Abi qualities in Mqamth Sasanian ( 15 ) :-

( He said : you is like thieves in the dirt, and especially what their eyes and Guenvst, and under what their achievements were collected and Qmst not safe attack ..... said : Alshad not this hypothalamus ! Insomnia and the Middle ....)

Thus yen $\mathrm{T}$ systems dialogue in the standings since the fifth century abandonment $\mathrm{Z}$ to the ninth century and varied content of e While we chose the previous types by counting $t \mathrm{t}$ some shrines despite the presence of some of the implications of social A. No other (16) dialogues should not be $\mathrm{Na} n$ shoulder more included by Here are the roses .

Dialogue based on the number of interlocutors : -

It may seem from the first glance that the dialogue must be between two or more, but the examiner finds that the maqamat were not built on one way in the dialogue, so the dialogue in it can be divided into : -

1. The ho of t mono " one speaker " : -

This type of dialogue is well-known in the public places in general. The speaker gives his message while there is a recipient, but it suffices to listen and the lack of answer does not mean the lack of communication between the interlocutors. The denominators used it to show rhetorical and linguistic capabilities, especially in Andalusia, while they were in fierce competition with the East, as the period from the fifth to the ninth century represented 
One of the most famous and most productive and competitive times with the East, and we find this in the shrine of " Omar Bin Shahid", as we find a one-sided dialogue from which Ibn Shahid reviews all his literary abilities in his text, including : - "So I listened, with a bell voice, in a monastery of a priest, and the village of Atah, all of which are pubs Dar Penguins, and a stadium To Cass ... the rooster said to them : Gentlemen, the young man among you is a joy for the youth, and there is no graying of light that differs with the bridles and dirt, and I have accompanied you for a while, and I praise God Almighty on your heads several secrets, I wake you up with magic, and I call the night and day ... ( 17 ) The dialogue here from one side is the " narrator " "the hero ", as he addressed his words and what he wanted to the addressees, while the recipients were satisfied with hearing .

The repeated discourse unilaterally " individual dialogue " in the denominator of " Abu Mohammed bin Malik Cordovan " in praise of " Mutassim bin Samadh " ( 18 )And his J built long been said to the praise of the king mentioned above, he said( 19 ) : - ( he said : ".... ye creating tempted yield him loose and generosity Fayad, not my Jhlinkm Ceftazidime, nor tempted by his kind, the sea is s d seen Dr. Z Guarbh, not Btam , and the viewer may infect Segah and not drifting ..." We find parties to the dialogue in the standings of the century, the fifth to the ninth Andalusian j g to $b$ by unilateral and another built is " built poetic " in the eighty - three beta preceded by an introduction of prose is another tales Kedia in terms of the history of Andalusia authorship as it was a review of a literary ( 20$)$.

2- Bilateral dialogue :

The bilateral feature of dialogue features as to be the presence of axes versus speaker mastery shows him via message me $\mathrm{n}$ t Aviate respond positively or negatively, Bumpy P " Brockelmann " " built " in published his comment on the shrines Hamadhani by saying, " spin a conversation in which between two people " ( 2 1) And lean shrines in this era on the bilateral dialogue technology ; some bilateral dialogues cover the whole set up , Wei built a dialogue on bilateral voice represent his point of view, the dominant voice, and it built in the Minister of writer Abi Amer bin Arqam ( 2 2) :-

" He said :" So and so son so and so " and what Ajtlat the text, and fulfilled the story

I said : I deserve a house to leave, so I am awash with the late pilgrims, not the foldable stages, the hope of the Kaaba of hopes, and the kiss of hopes, in us I am walking, and the displacement has come ...

So I said : Who is the man?

He said : ... I said : Every fire is a fire ..."

Here the narrative varies dialogue, expanding should the representative scene of dialogue parts compatibility, or narrative context " Almqama " in which he made, as reported by Bstvil d (2 3) .

It is also from the bilateral dialogue that we find him in a maqamah for the residence of al-Shalabiyya and attributed to Abu al-Walid bin Sayyid Amir (24) It is estimated that the Andalusian culture is blessed with a renaissance, the clearest of which is the emergence and strength of the Andalusian scholarly personality . )25) ... He said : Was I a subject or a statement that was exposed? ! So I said, may God have mercy on you, I mean myself, longing for the priority of my current sings, so he sympathized with Jenan, and he greeted Balban, and he said : O Bin Al- Karam, how is the effect of cypress, that is Balkh or Murr? I said : Yes, from one of them, and he said the lineage or the uncle of your uncle, get out of your turmoil, and connect you to your greatest concern, I said : the people of this palace! He said : One of them was let down, and they were deprived of them, until their command was not what ...

And from the sanctuary of the mihrab of Muhammad al-Wadi, Ashi said :2 6) ... Fateh said : When I heard those pronounced words, and the extra purposes contemplated him, and the contemplation dictated him, and I hope that he will be the owner of the images of Saad bin Mansour, so the mask was revealed, from a masked morning, and he spoke, but not but a stutterer, so I smelled his irrigations and insulted him, so he said to him, and I said Saad : Saad said, the nights brought us together without a promise ... ".

The group dialogue is divided into :

A - Dialogue between an individual and a group : -

B - Dialogue between multiple persons : -

1- Individual dialogue with the group :

As a result of the definition of dialogue in the glossary of literary terms, we find that dialogue is the exchange of speech between two or more or a mode of communication whereby people exchange and alternate on sending and receiving(2 7 ) As we find this type of dialogue present in Andalusian stations, it shows the individual's ingenuity in front of the group, and there are multiple categories of dialogue in it. Dialogue in the maqamah cooperates with the characters to build the event and creates cohesion between the parts of the maqamah. For example, we find in the palm tree shrine of Abu Hafs bin Bard, as the maqamah starts with a supplication addressed to no We know him while he is out of the maqamah. He puts the result by addressing a group of people who blame anyone, because when he reaped the date of his palm he kept silent, so that he did not covet a share of his greed, so the palm tree owner apologized that he was not aware of the cost of this with its fruit ... so he said with the text of the maqama addressing the community ... if I learned that you do this costs, and to him This conflict, I seized it on you, and made the rule of his grandfather to you, but, God willing, in the year of the 
nose, he yielded you, a breath for you, and a treasured asset on you ... As for us, we drew that kit in our hearts, and we entrusted it with our guardians, and as for you, it drained the dust, and delivered it to it To the hand of wear and tear ... He said : With my father you are, and God has appointed you to depend on where you were, I see you as a lost or lost appeals, but I have missed, so ask, maybe you fell on the expert, and they consulted, so the advice opens the closing of matters ... " Here we find the dialogue with the group and the narrator's presentation of his philosophy and wisdom. The writer does not find any need to direct the dialogue towards the group to show the importance and magnitude of the information to the extent of lack Depending on an individual in the speech, he bites and advises a whole group, and these talkative scenes are not achieved unless the exchange is with the group .

2- Bin Hawar More than one individual :

It is a dialogue that is managed by more than one person, as the parties to the conversation interact with several people who are brought together by companionship or a specific topic among which the verbal message is produced, and such a dialogue is seen in a position made by Al-Fath bin Khaqan against Professor Abi Muhammad Al-Batloussi.( 28 )........ I was told here by the Serbian Sheikh Abu Muhammad al-Batlousi, the ills of the ills, the recovery of the sickness of illness, he went to his request, and the imam of the immortal aunt, so I followed my longings to him,... I asked them from the great Sheikh, and one of them said the ugliness of the Sheikh of his religion, he hid the stick, and he inherited his resentment as The pebbles ... Then Yusuf bin Khalil came to his long companion, and he said : I asked you rightly next door, did you not mention the hadith on the Day of the House, because the hadith is courageous and the speech is pardoned and pardoned, and he said : I tell you a stranger, and evoke a suspicious suspicion about you. Al-Hawaghar has swept ... ".

As Ibn Hisham, the hero of the Maqamah, arrives in the city of Valencia from Andalusia, he enumerates her descriptions and then asks about the writers in it, so he says to him, here is the Sheikh Al-Serbi and he also meets another with a boy and another friend of his. The boys compete in attaching to the charges of immorality, and here we find dialogue between more than one individual, each of whom has a voice in the dialogue, as the dialogue moves between individuals and the others remain listeners, starting with the narrator and then the other people, as we find the difference of the interlocutors, because the dialogue is in councils in more than one person, so the speaker makes the dialogue The rest will listen to him until his turn comes to Ba Return and thus based on the different types of dialogue .

The dialogue can also be divided into two types according to the character's voice. If it is heard or implied, we can divide it into :

1- External Dialogue " Monologue - Single "

2- Internal dialogue " Aldialloj - double "

1- External Dialogue " Monologue - Single "

External dialogue is a form of dialogue that takes place between the characters with each other and is divided into a direct dialogue that takes place between the characters of the story directly as the speaker directs his words directly to a direct recipient and they exchange the words between them ( 29). The form of the indirect transmitter and the carrier here " does not preserve the original word, but introduces it in the letter listed " ( 30 ) That is, it constitutes my style of making the ideas assigned to the characters in the form of sayings( $\left.\begin{array}{ll}3 & 1\end{array}\right)$ Dialogue here requires the presence of an apparent external appearance of the characters represented by the sender and the recipient, "the future " in a specific time and place, each character taking its role in speaking within a scene within the literary narrative text .

It seems that this type of dialogue prevails over the maqamat in general, and the other type of dialogue does not disappear completely. The narrator's time transmits the dialogue to us, and at other times the characters talk to each other. When reviewing the dialogue, we find that in the position of Eid by Ibn Al-Maraba Al-Azdi( 32 ) . So I said to al-Qassab : How much do you request it, provided that you neglect the price or pay it ... He said : I want to give him a reward for it, and now he will have a slaughterhouse for it ...

I said : Listen up, and don't miss the footage .

He said : Forget it, and take it as a gift .

I said : Yes, so he broke the conscience for me, and he reflected on him with the hilum and the qatir.

He said : Twenty dinars are included in it .

And in a maqam of Abu Al-Mutref Abdul Rahman bin Fattouh( 33 )

He said : He is the heir in which you are my trigger, so tell me the reason why you should go home, I said to him : You have suffered a stingy morality, with a lack of equity ...

He said : God's heart is your heart, and your side is blamed, then it is gone .

As we find the dialogue appears directly between the characters and adopted the form of direct question and answer and the narrator used the form of the verb to them . He said, I said, "It was not complicated to reveal his ability to manage the topic of the dialogue. The stations are a literary - linguistic - scientific competition in which the denominator shows all his possibilities to effect the effect." The reader .

And from the abode of the minister, writer Abi Amer bin Arqam( 34 ): 
So and so and so said: When I clarified what was stipulated, and I fulfilled what was narrated

I said : deserving of home pools, Fjt Murahaleen, not foldable stages .... Fbana I walk .... If it suit a boy, witnessing his pride ...

So I said: Who is the man?

He said :

- I am a person who does not attribute my moral defilement and refute it

- mm stippled in honor house and the branch grows around the branch

- So healthy when he says to them, " Eggs of the faces" are lumpy teeth

- Do not know the fault of their neighbor, as they are keeping his neighborhood astute

I said : In every stick of fire ...

He turned towards me, saying : The spring is knocking each other ...

He said : Where is your mother? What is your concern?

I said : Granada .

So he said : Where is the compassion surrounding pound, dew and dew

Here the dialogue revolves between two people, one of whom is the narrator " so-and-so-so-and-so-called " and the other is from the sons of Jah and Al-Khawas, who is the hero, and the conversation begins. The first question revolves around Granada itself, so the boy asks : Where is your mother? What concerns you ... "to seal it with verses .

Based on the foregoing, we find that the external dialogue has a great presence in the maqam, because the maqami places him as interlocutors for several reasons :

First : The multiplicity of dialogue leads to the multiplicity of characters in which the shrine appears .

Second : The wide area that plurality of dialogue gives to highlight its scientific linguistic energies .

Third : Pluralism leads to the diversification of topics and the presentation of whatever ideas he wants in the language of others without being subject to criticism, it is only a vector .

The dialogue alternates between the characters in the hadith in the context of the scene inside the maqam text directly. ( 35 )

B - The Internal Dialogue : "The Single Monologue "

It is he who revolves within the soul, that is, the personality itself is a speaker and recipient of a " hearing " or a fictitious owner, and his field is the soul and the interior, that is, it is a silent dialogue, as Leon Sarmelian said.( 3 6 )Kassir expresses a feeling of loneliness and alienation, and we find it a little in the public places and in our current study of the shrines for the period from the fifth century to the ninth century $\mathrm{AH}$, as the shrine is often a clear voice in front of other voices represented by the characters, and it is the most appropriate for the shrines, as we find in the shrine of Abu Muhammad Bam Malik Al-Qurtubi in Praise of Mutasim bin Samadh( 37 )When he talks about his want, deprivation, degree, and children, or blames himself for not winning him, praised only by the tongue, the voice here is an internal voice, a dialogue with himself by blaming, sometimes, and complaint at other times, as he says: "And by the fact that my aid to him is not with the tongue, without the sunnah, I obey before him for grief, and I crowd before him not Koran to Kak and if I do not spawn like a fluff of cats, they crawl into his sleep, I have a creeping beard, so they will heal my sins, and they will bleed with me, I would be ridden from his glorified and glorious feasibility, and I fell from his firm, sedimentary call and was arrested from his tender base ..."

Including what was mentioned in the Qutbiyah shrine (3 8 )"The balance of notables by virtue of time is the establishment of so and so so and so ."

"I said to myself : A colleague has good and good news, and he has an eye for impact." Despite the limitation of dialogue, it came in the form of "direct" self- presentation. We note that the lack of internal dialogues is the character of the narrator and the hero tends to the external dialogue to show ingenuity in front of their competitors to fabricate the causes while not Respond to the solemnity or artistic reflux, and the stream of consciousness and see the internal dialogue in the Maqamah Mahalabiya(3 9) We see also the external dialogue , which is one of the longest debates in the standings that we teach in this period while we find the Palace of internal dialogue and confined to sentences indicating the position of the hero of the narrator of the character in the set up and he has also repeated here, he said : " I said to myself : the rest of the eye refers to They were stirred by the "sim of time", the hostility of the free .

When I stood up ...

It is one of the most pleasant maneuvers with the soul and its internal dialogues in the position of preference of the palm tree over the vineyard of Abu Al-Hassan Al-Nabahi Al-Malaki( 40 ).

He quoted himself ... " And it was only for me to convey my article, so the speaker said : I volunteer the answer, and God rewarded him, so that every questioner knows that the preference of palm trees over grapes is one of the issues in which an ungrateful greed is not heard, even if they are brothers It was watered with one water ... " He speaks in a monologue himself with a dialogue with her, as this maqam was characterized by a wit on the subject as it included a personalization of the palm tree, its maneuvers and dialogue, in a literary style 
using the symbol .

Margins : -

(1) Glossary of Literary Terms Contemporary : 148 ( presentation and translation of Said Alloush, Dar Lebanese book - Beirut - Sucbric, Casablanca, i 1, 1985 m ).

(2) Looking : methods of dialogue in the poetry of Ibn Al-Wardi, d Abdullah Ahmad Al-Wattwat : 41 " Scientific Journal of the College of Education, University of Misrata, Libya, No. 8/2517 m ."

(3) Seen : Glossary of theatrical and theatrical terms, d . Ibrahim Hamada : 135 " Dar Al-Shaab, Cairo, 1971 AD " and looks at : Literary Dictionary, Jabour Abdel-Nour : 100 " Dar Al-Alam for Millions, 1st edition, Beirut, 1979".

(4) Art of Literature / 148 , Tawfiq Al-Hakim, Lebanese Book House, Beirut, 2nd edition, 1393 AH -1973 CE .

(5) Dialogues with the Umayyad period " literary study " Khalil Ibrahim, PhD thesis / p . 8 / Baghdad University / Arts, $1990 \mathrm{~m}$.

(6) Ammunition : 1/2/786-787.

(7) ammunition : 1/2/786-887\} ammunition in the virtues of the people of the island of Ibn Bassam Aelchentrini T. (542 AH ) to achieve : d. Ihsan Abbas Culture House, Beirut, $1975 \mathrm{~m}$.

(8) Ammunition : 1/2 / 674-685.

(9) See : The chatter of dialogue with the Noble Qur'an, “a stylistic job study, " Suhail Kamel's victory : 71 , Dar Al-Jawhara, 1st floor, Amman.

(10) m . Pp. 1/2 / 675-676.2003 m .

(11) Necessary denominators : 356 and 547.

(12) Nominal Standings : 356-357.

(13) Rehana book : 2 / 316-334\} Rehana, the writers and Nagaa al-Muntab \{, Lisan Al-Din Bin Al-Khatib (d. $776 \mathrm{AH}$ ) investigation Muhammad Abdullah Anan, Al-Khanji Library, Cairo, I 1,1981 AD .

(14) standings Indispensability : 23\} shrines Indispensability, Abu Taher Mohammed Ben Youssef ( T. 538 e ) achieve Ahmed Badr classification, the Egyptian General Authority of the book 1982 AD .

(15th) Set up in letters Ibn Abi qualities : 42-449.

(16) Riyadh flowers are seen : 1/117, Nafat al-Tayyib : 5 / 40-46.

(17) Ammunition : 1/2 / 674-685.

(18) $\mathrm{m} . \mathrm{N}: 1 / 2 / 741-752$.

(19) $\mathrm{m} . \mathrm{N}: 1 / 2 / 741$.

(20) See : From Al-Andalus Residence : The Annals of the Tunisian University, No. 28: 162.

(21) See : Anecdotal Structure in the Letter of Expansion and Hurricanes, p . 35.

(22) Al- Aqyan Necklaces : 372-374.

(23) The art of the playwright" translation d . Reni stage " Anglo - Egyptian Library, Cairo, p . 218 , 1964 AD .

(24) messages and shrines of Andalusian : 160-171\} Author unknown, achievement : $d$. Fawzi Saad Issa, the rise of knowledge Alexandria .

(25) Malaga Writers : 292-298\} Quoted from the book ....

(26) Andalusian Letters and Standings : 82-92.

(27) seen : Glossary of Contemporary Literary terms : 78\} Said Alloush Dar Arab Book, Beirut, Library University Press, Casablanca, $1985 \mathrm{~m}$.

(28) Andalusian messages : p . 93-100, author unknown achievement : d . Fawzi Saad Issa, Al-Maarif facility in Alexandria, 1st edition, 1989 AD .

(29) seen : discourse analysis novelist happy pumpkin, p . 67, 1989 AD .

(30) $\mathrm{m}$. N : 189 " The Arab Cultural Center for Printing, Publishing and Distribution, Beirut - Lebanon, 2nd edition, 1993".

(31) dialogue and background mechanisms and issues / $36 \mathrm{~d}$. Sadiq NOD, Mskliani for publication and distribution, i 1 , Tunisia, 2009 AD .

(32) Briefing in the News of Granada : 3 / 425-432 by Sanadin bin Al-Khatib Abu Abdullah Muhammad bin Abdullah ( d. $776 \mathrm{AH}$ ), investigation by Mohamed Abdel Anan, Al-Khanji Library, Cairo, I 1, 1974 AD .

(33) ammunition s $1 / \mathrm{m} 2 / 786-787$, ammunition in the virtues of the people of the island, the son of Bassam Aelchentrini, Ali bin Bassam ( v 542 e ) achieve : d . Ihsan Abbas, the House of Culture Beirut, $1975 \mathrm{~m}$.

(34) necklaces Alaqian and fortuitous objects, son Hakan, 372-374 " necklaces Alaqian, Abu Nasr bin Mohammed Al Fath ( T 529 e ) achieve d. Hussein Khryosh, Al - Manar Library, Amman, 1989 AD "

(35) See : Narrative Dialogue : 41 " Narrative Narration, Its Techniques and Narrative Relationships, Fateh Abdel Salam, The Arab Institution for Studies and Publishing, 1st edition , Beirut, 1999 AD ."

(36) See : the stream of modern individual and internal thought, translation : Abd al-Rahman Muhammad Abd al-Ridha, Journal of Foreign Culture, No. (3), $1982 \mathrm{~m}: 85$.

(37) Ammunition : 1/2 February 741-752. 
(38) messages and shrines of Andalusian : 139-156" seen the survey " e 6

(39) Ibid : 160-171.

(40) It appeared in a research paper published by the Tunisian University Yearbooks ( No. 27 , 1988 CE, 207218 , the investigation of Hasna Trabelsi )

\section{References}

(1) Glossary of Contemporary Literary Terms : Display and provide translation Alloush Said, Dar Lebanese book - Beirut - Sucbric, Casablanca, i 1, 1985 AD .

(2) Dialogue methods in the poetry of Ibn Al-Wardi, d. Abdullah Ahmad Al-Wattwat : 41 " Scientific Journal of the College of Education, University of Misrata, Libya, No. 8/2517 m ."

(3) A dictionary of theatrical and theatrical terms, d. Ibrahim Hamadeh : " Dar Al-Shaab, Cairo, 1971 AD " and looks at : Literary Dictionary, Jabour Abdel-Nour : 100 " Dar Al-Alam for Millions, 1st edition, Beirut, 1979".

(4) Art of Literature : Tawfiq Al-Hakim, Lebanese Book House, Beirut, 2nd edition, 1393 AH -1973 CE .

(5) Dialogues with the Umayyad period " literary study " Khalil Ibrahim, PhD thesis / p . 8 / Baghdad University / Arts, $1990 \mathrm{~m}$.

(6) Ammunition : - ammunition in the virtues of the people of the island of Ibn Bassam Aelchentrini T. (542 AH ) to achieve : d . Ihsan Abbas Culture House, Beirut, $1975 \mathrm{~m}$.

(7) Rehana the book : Rehana the writers and Nagat Al-Muntab \{, Lisan Al-Din Bin Al-Khatib ( d. 776 AH ), investigation by Muhammad Abdullah Anan, Al-Khanji Library, Cairo, I 1, 1981 AD .

(8) standings Indispensability : shrines Indispensability, Abu Taher Mohammed Ben Youssef ( T. 538 e ) achieve Ahmed Badr classification, the Egyptian General Authority of the book 1982 AD .

(9) League of dialogue with the Holy Quran " functional study of stylistic " Suhail full win : 71, Dar Al Jawhara, i 1 , Amman 2003 m .

(10) Established in the Epistles of Ibn Abi Al- Khasal: 42-449.

(11) From a residence in Andalusia : Annals of the Tunisian University, No. 28: 162.

(12) Anecdotal structure in the message of expansion and storms .

(13) Al-Aqyan necklaces :

(14) The art of the playwright " translation d . Reni stage " Anglo - Egyptian Library, Cairo, p . 218 , 1964 AD .

(15) messages and shrines of Andalusian : 160-171\} Author unknown, achievement : d . Fawzi Saad Issa, The Origination of Knowledge Alexandria \{.

(16) Malaga Writers : 292-298\} Quoted from the book ... \{.

(17) seen : Glossary of Contemporary Literary terms : Said Alloush Dar Arab Book, Beirut, Library University Press, Casablanca, $1985 \mathrm{~m}$.

(18) Andalusian Messages : Author unknown achievement : d . Fawzi Saad Issa, Al-Maarif facility in Alexandria, 1st edition, 1989 AD .

(19) Analysis of the narrative speech by Saeed Yektan, 1989 AD .

(20) m . N : 189 " The Arab Cultural Center for Printing, Publishing and Distribution, Beirut - Lebanon, 2nd edition, 1993".

(21) Dialogue backgrounds, mechanisms and issues , d. Sadiq NOD, Mskliani for publication and distribution, i 1, Tunisia, 2009 AD

(22) Briefing in the News of Granada : 3 / 425-432 by Sanadin bin Al-Khatib Abu Abdullah Muhammad bin Abdullah ( d. 776 AH ), investigation by Mohamed Abdel Anan, Al-Khanji Library, Cairo, I 1, 1974 AD .

(23) ammunition s $1 / \mathrm{m} 2 / 786-787$, ammunition in the virtues of the people of the island, the son of Bassam Aelchentrini, Ali bin Bassam ( v 542 e ) achieve : d. Ihsan Abbas, the House of Culture Beirut, $1975 \mathrm{~m}$.

(24) necklaces Alaqian and fortuitous objects, son Hakan, 372-374 " necklaces Alaqian, Abu Nasr bin Mohammed Al Fath ( T 529 e ) achieve d . Hussein Khryosh, Al - Manar Library, Amman, 1989 AD "

(25) See : Narrative Dialogue : 41 " Narrative Narration, Its Techniques and Narrative Relationships, Fateh Abdel Salam, The Arab Institution for Studies and Publishing, 1st edition, Beirut, 1999 AD ."

(26) stream of modern thought and individual internal, translation : Abdul Rahman Mohammed Abdul Ridha, foreign culture magazine, Issue $3,1982 \mathrm{~m}: 85$.

(27) Ammunition : 1/2 February 741-752.

(28) Andalusian Letters and Standings: 139-156 " Consider the Survey " 